\title{
TAHAP DEFINE DAN DESIGN BAHAN AJAR MATEMATIKA SMP DENGAN PENDEKATAN REALISTIC MATHEMATIC EDUCATION (RME) BERBASIS BUDAYA LOKAL UNTUK MENANAMKAN NILAI- NILAI BUDAYA PEKALONGAN
}

\author{
Dewi Mardhiyana*, Nur Baiti Nasution, Syita Fatih 'Adna \\ Program Studi Pendidikan Matematika Universitas Pekalongan \\ Korespondensi: dewimardhiyana139@gmail.com
}

\begin{abstract}
Pekalongan City is famous for the nickname "creative city" which is rich in tradition and culture. Tradition and culture need to be preserved by integrating cultural values into the realm of education, especially mathematics teaching materials. This is because math is considered a difficult subject for middle school students. Mathematical material will be easier to learn by students if it contains contextual problems (Realistic Mathematic Educatioan) that are often found in everyday life. However, the problems faced by teachers today are the lack or unavailability of SMP teaching materials whose contents are integrated with local culture, especially culture in Pekalongan City. This study aims to produce junior high school mathematics teaching materials with a Realistic Mathematic Educatioan (RME) approach based on local culture to instill the cultural values of Pekalongan City. This type of research is research and development ( $\&$ D), which contains 4 stages, namely Define, Design, Develop, and Disseminate. This article only discusses the define and design stage in developing mathematics teaching materials based on Pekalongan local culture. At the define stage, a needs analysis was carried out in the form of a survey of junior high school students in Pekalongan by doing mathematics learning by providing worksheets containing the local culture of Pekalongan. This aims to find out the teaching materials needed by the rest. In addition, interviews were also conducted with junior high school mathematics teachers who were familiar with junior high school mathematics material and Pekalongan local culture. The survey results for junior high school students show that all students have never seen a worksheet that integrates cultural elements. They also stated that the learning done was more interesting and impressive, because it contained the problem of the context in the form of batik they usually encountered. The results of interviews with junior high school mathematics teachers stated that the integration of Pekalongan cultural values needs to be incorporated into mathematics subjects to make them more interesting for students to learn. The result of the define stage shows that the teaching material developed must contain Pekalongan's local culture, contain many illustrations, have a sufficient number of questions, and are relevant to junior high school mathematics material according to the applicable curriculum. Next, the teaching material design stage is carried out. This stage starts with analyzing the curriculum in the form of analysis of Core Competencies and Basic Competencies. Next, determine the framework of teaching materials which includes determining the way the material is presented which includes the initial narrative, material, conclusions, problem, and and famous figure in mathematics on each chapter. From the designing process, it was obtained some narration about ocal culture that can be linked to mathematics material such as the narration about Lopisan, Syawalan air balloon, krupuk usek, and Udan Liris batik motive.
\end{abstract}

Keywords: Define and design, Developing teaching material, Local culture of Pekalongan, RME

\begin{abstract}
ABSTRAK
Kota Pekalongan terkenal dengan julukan "kota kreatif" yang kaya akan tradisi dan budaya. Tradisi dan budaya tersebut perlu dilestarikan dengan mengintegrasikan nilai-nilai budaya ke ranah pendidikan, khususnya bahan ajar matematika. Hal ini disebakan karena matematika dianggap sebagai mata pelajaran yang sulit bagi siswa SMP. Materi matematika akan lebih mudah dipelajari oleh siswa jika berisi masalah kontekstual (Realistic Mathematic Educatioan) yang sering dijumpai dalam kehidupan sehari-hari. Namun, permasalahan yang dihadapi guru saat ini adalah kurangnya atau belum tersedianya bahan ajar SMP yang isinya terintegrasi budaya lokal, khususnya budaya di Kota Pekalongan. Penelitian ini bertujuan untuk menghasilkan bahan ajar matematika SMP dengan pendekatan Realistic Mathematic Educatioan (RME) berbasis budaya lokal untuk menanamkan nilai-
\end{abstract}


nilai budaya Kota Pekalongan. Jenis penelitian ini adalah research and development (R\&D), yang memuat 4 tahapan, yaitu Define (Pendefinisian), Design (Perancangan), Develop (Pengembangan), dan Disseminate (Penyebaran). Artikel ini hanya membahas tahap define dan design pada pengembangan bahan ajar matematika berbasis budaya lokal Pekalongan. Pada tahap define, dilakukan analisis kebutuhan berupa survei ke siswa SMP di Pekalongan dengan melakukan pembelajaran matematika dengan memberikan lembar kerja yang berisi tentang budaya lokal Pekalongan. Hal ini bertujuan untuk mengetahui bahan ajar yang dibutuhkan oleh sisa. Selain itu juga dilakukan wawancara ke guru matematika SMP yang familiar dengan materi matematika SMP dan budaya lokal Pekalongan. Hasil survey ke siswa SMP menunjukkan bahwa semua siswa belum pernah melihat lembar kerja yang mengintegrasikan unsur budaya. Mereka juga menyatakan bahwa pembelajaran yang dilakukan lebih menarik dan mengesankan, karena memuat masalah konteks berupa batik yang biasa mereka jumpai. Hasil wawancara dengan guru matematika SMP menyatakan bahwa pengintegrasian nilai budaya Pekalongan perlu dimasukkan ke dalam mata pelajaran matematika agar lebih menarik untuk dipelajari siswa. Hasil tahap define menunjukkan bahwa bahan ajar yang dikembangkan harus memuat budaya lokal Pekalongan, memuat banyak gambar ilustrasi, memiliki jumlah soal yang cukup, dan relevan dengan materi matematika SMP sesuai kurikulum yang berlaku. Selanjutnya, dilakukan tahap design bahan ajar. Tahap ini dimulai dengan analisis kurikulum berupa analisis Kompetensi Inti dan Kompetensi Dasar. Selanjutnya menentukan kerangka bahan ajar yang meliputi penentuan cara penyajian materi yang meliputi narasi awal, materi, kesimpulan, latihan soal, dan tokoh matematika. Dari tahap perancangan diperoleh bahwa beberapa budaya Pekalongan yang dapat dikaitkan dengan materi matematika SMP adalah budaya lopisan, balon udara, krupuk usek, dan batik udan liris.

Kata Kunci: Tahap define dan design, Pengembangan bahan ajar, Budaya lokal Pekalongan, RME

\section{PENDAHULUAN}

Pekalongan merupakan kota yang terkenal dengan tradisi dan budayanya. Tradisi dan budaya yang sampai saat ini masih dilestarikan, yaitu acara lopisan pada saat syawalan, simtudorror, tari sintren, tari jlamprang, seni membatik, dan lain sebagainya. Selain itu, saat ini masih marak dengan adanya musik rampak yang populer di kalangan masyarakat Kota Pekalongan. Semua tradisi dan budaya yang ada saat ini seharusnya dilestarikan sebagai wujud julukan Kota Pekalongan "kota kreatif".

Salah satu cara untuk menjaga kelestarian tradisi dan budaya di Kota Pekalongan adalah dengan mengintegrasikan nilai-nilai budaya ke ranah pendidikan. Hal ini sesuai dengan tujuan pendidikan nasional Indonesia. Berdasarkan Pancasila dan UUD RI tahun 1945, pendidikan nasional bertujuan untuk mengembangkan kemampuan dan membentuk watak serta peradaban bangsa yang bermartabat dalam rangka mencerdaskan kehidupan bangsa. Selain itu juga bertujuan untuk mengembangkan potensi siswa agar menjadi manusia yang beriman dan bertakwa kepada Tuhan Yang Maha Esa, berakhlak mulia, sehat, berilmu, cakap, kreatif, mandiri, dan menjadi warga negara yang demokratis serta bertanggung jawab.

Untuk mewujudkan tujuan pendidikan nasional, proses pembelajaran pada satuan pendidikan diselenggarakan secara interaktif, inspiratif, menyenangkan, menantang, memotivasi siswa untuk berpartisipasi aktif, serta memberikan ruang yang cukup bagi prakarsa, kreativitas, dan kemandirian sesuai dengan bakat, minat, dan perkembangan fisik serta psikologis siswa. Cara yang dapat ditempuh oleh guru dalam menciptakan proses pembelajaran yang efektif adalah dengan menggunakan bahan ajar yang di dalamnya mengintegrasikan nilai-nilai budaya.

Bahan ajar adalah seperangkat materi/substansi pembelajaran (teaching material) yang disusun secara sistematis, serta menampilkan sosok utuh dari kompetensi yang akan dikuasai siswa dalam kegiatan pembelajaran. Pada dasarnya, bahan ajar berisi tentang 
pengetahuan, nilai, sikap, tindakan, dan ketrampilan. Bahan ajar tersebut dapat berisi pesan, informasi, dan ilustrasi berupa fakta, konsep, prinsip, dan proses yang terkait dengan pokok bahasan tertentu yang diarahkan untuk mencapai tujuan pembelajaran.

Matematika merupakan salah satu mata pelajaran yang yang perlu dipelajari oleh siswa. Menurut Suherman (2003), matematika adalah ilmu deduktif, sehingga generalisasi, sifat, teori atau dalil harus dibuktikan secara deduktif. Hudojo (1988) menambahkan bahwa matematika adalah hal yang berkenaan dengan ide-ide atau konsepkonsep abstrak yang tersusun secara hirarkis dan penalarannya deduktif. Terkait dengan kegunaan belajar matematika, dalam NCTM (2000) dijelaskan bahwa belajar matematika dapat menimbulkan rasa (sense) ide-ide matematika dan belajar matematika juga bisa menciptakan keterampilan dan pengetahuan dalam memecahkan masalah.

Masalah penting yang sering dihadapi guru dalam kegiatan pembelajaran matematika adalah memilih atau menentukan bahan ajar yang tepat dalam rangka membantu siswa mencapai kompetensi. Hal ini disebabkan karena dalam kurikulum atau silabus, materi bahan ajar hanya dituliskan secara garis besar dalam bentuk "materi pokok". Bahan ajar yang selama ini ada hanya berupa buku teks yang belum mencerminkan integrasi nilai-nilai budaya setempat. Berdasarkan hal tersebut, guru seyogyanya mampu mengembangkan bahan ajar matematika yang sesuai dengan budaya setempat.

Dalam pengembangan bahan ajar terdapat sejumlah alasan mengapa harus mengembangkan bahan ajar. Menurut Depdiknas (2008), alasan perlunya pengembangan bahan ajar adalah (a) pengembangan bahan ajar harus disesuaikan dengan tuntutan kurikulum, artinya bahan ajar yang dikembangkan harus sesuai dengan kurikulum; (b) pengembangan bahan ajar harus disesuaikan dengan karakteristik sasaran, karena terkadang bahan ajar yang dikembangkan orang lain tidak cocok dengan siswa sehingga bahan ajar yang dikembangkan sendiri dapat disesuaikan dengan karakteristik sasaran; dan (c) pengembangan bahan ajar harus mampu menjawab kesulitan dalam belajar, karena terkadang terdapat sejumlah materi yang seringkali sulit dipahami oleh siswa sehingga perlu dikembangkan bahan ajar yang tepat.

Dalam mengembangkan bahan ajar, perlu juga diperhatikan tentang prinsip pemilihan materi. Menurut Depdiknas (2006), prinsip pemilihan materi antara lain (a) prinsip relevansi artinya keterkaitan, sehingga materi pembelajaran hendaknya relevan atau ada kaitannya dengan pencapaian Kompetensi Inti dan Kompetensi Dasar, (b) prinsip konsistensi artinya keajegan, misalnya jika kompetensi dasar yang harus dikuasai empat macam, maka bahan ajar harus menampilkan empat macam kompetensi dasar tersebut, dan (c) prinsip kecukupan artinya materi yang diajarkan hendaknya cukup memadai dalam membantu siswa menguasai kompetensi dasar yang diajarkan, sehingga materi tidak boleh terlalu sedikit dan tidak boleh terlalu banyak.

Bahan ajar matematika yang sesuai dengan budaya setempat, sehingga didasarkan pada salah satu pendekatan. Salah satu pendekatan yang dapat diterapkan dalam pengembangan bahan ajar matematika adalah pendekatan Realistic Mathematic Education (RME). Realistic Mathematics Education (RME) adalah sebuah pendekatan pembelajaran matematika yang dikembangkan Freudenthal di Belanda. Gravemeijer (1994) menjelaskan bahwa RME dapat digolongkan sebagai aktivitas pemecahan masalah, mencari masalah dan mengorganisasi pokok persoalan. 
Gravemaijer dalam Hidayanto, dkk (2013) mengungkapkan bahwa terdapat tiga prinsip utama dalam mendesain pembelajaran berbasis RME yaitu penemuan (kembali) secara terbimbing (guided reinvention), fenomena didaktik (didactical phenomenology), pemodelan (emerging models). Sedangkan Zulkardi (2001) menambahkan terdapat lima karakteristik pembelajaran berbasis RME, yaitu 1) penggunaan masalah kontekstual sebagai titik awal pembelajaran, 2) penggunaan model, situasi, skema dan simbol-simbol sebagai jembatan ke arah matematika formal, 3) penggunaan kontribusi siswa (sumbangan pemikiran dari siswa), 4) penggunaan metode interaktif dalam belajar matematika, dan 5) adanya keterkaitan antartopik dalam matematika.

Dalam RME, matematika realistik yang dimaksudkan dalam hal ini adalah matematika sekolah yang dilaksanakan dengan menempatkan realitas dan pengalaman siswa sebagai titik awal pembelajaran. Masalah-masalah realistik digunakan sebagai sumber munculnya konsep-konsep matematika atau pengetahuan matematika formal. Matematika realistik yang dimunculkan dalam bahan ajar adalah masalah kontekstual yang berbasis budaya lokal. Betancourt, et al (Woolfolk, 2009) menyatakan bahwa budaya adalah pengetahuan, ketrampilan, aturan, tradisi, kepercayaan, dan nilai-nilai yang memedomani perilaku di sekelompok orang tertentu maupun karya seni dan artefak yang dihasilkan dan diteruskan ke generasi berikutnya. Definisi ini senada dengan Ormrod (2003) yang menyatakan bahwa budaya merupakan hasil budi daya manusia yang dapat berupa pengetahuan, ketrampilan, aturan, tradisi, kepercayaan, tingkah laku, dan karya seni yang dihasilkan dan diteruskan suatu kelompok sosial ke generasi berikutnya.

Mengingat pentingnya budaya dan pendidikan sebagai usaha untuk membentuk manusia yang berpengetahuan, maka dalam dunia pendidikan khususnya pembelajaran matematika perlu membahas segala sesuatu yang berkaitan dengan budaya. Hal ini diperkuat dengan pendapat NCTM (2000) yang berpendapat bahwa matematika adalah salah satu prestasi budaya dan intelektual terbesar umat manusia, dan warga negara harus mengembangkan apresiasi dan pemahaman tentang prestasi itu, termasuk aspek estetika bahkan rekreasi. Hal ini bermakna, matematika merupakan bagian dari warisan kebudayaan, sehingga untuk memahami dan menggunakan matematika dalam kehidupan sehari-hari hendaknya dihubungkan dengan konteks kebudayaan.

Untuk mengintegrasikan nilai-nilai budaya dalam materi pembelajaran perlu dikaji mengenai elemen dan wujud budaya. Samovar, Porter, \& McDaniel (2010) mengemukakan bahwa terdapat lima elemen budaya yaitu sejarah, agama, nilai, organisasi sosial, dan bahasa. Koentjaraningrat (2009) juga mengemukakan tentang wujud-wujud budaya yaitu diantaranya adalah wujud (a) kebudayaan sebagai suatu kompleks dari ide, gagasan, nilai, norma, peraturan, dan sebagainya; (b) kebudayaan sebagai suatu kompleks aktifitas serta tindakan berpola dari manusia dalam masyarakat; dan (c) kebudayaan sebagai benda-benda hasil karya manusia.

Untuk menggunakan budaya lokal dalam pembelajaran matematika harus terlebih dahulu dikaji mengenai pengertian kata lokal. Lokal berarti tempat atau wilayah setempat. Oleh karena itu, budaya lokal adalah hasil cipta, rasa, dan karsa manusia yang berupa ide, aktifitas, dan benda-benda fisik dari suatu masyarakat di wilayah tertentu. Dalam penelitian digunakan beberapa wujud budaya lokal di Kota Pekalongan yang berupa permainan tradisional, makanan tradisional, kesenian tradisional, upacara adat dan keagamaan yang dapat dipandang sebagai wujud budaya konkret yaitu aktivitas dan motif 
batik, serta benda-benda peninggalan sejarah yang dipandang sebagai wujud budaya konkret yaitu arsitektur dan artefak.

Melalui pendekatan RME berbasis budaya lokal, siswa dapat merasa bahwa matematika merupakan mata pelajaran yang berguna dalam kehidupan sehari-hari. Siswa juga dapat merasa bahwa kebudayaan lokal yang ada di sekitar mereka merupakan sesuatu yang menarik. Dengan demikian, diharapkan nilai-nilai budaya dapat melekat dalam diri siswa sehingga tidak hilang ditelan zaman.

\section{METODE PENELITIAN}

Permasalahan yang dihadapi guru saat ini adalah kurangnya atau belum tersedianya bahan ajar SMP yang isinya terintegrasi budaya lokal, khususnya budaya di Kota Pekalongan. Padahal budaya di Kota Pekalongan perlu untuk dilestarikan agar keberadaannya tidak punah. Salah satu cara melestrasikan budaya Kota Pekalongan adalah dengan pengintegrasian budaya melalui bahan ajar. Bahan ajar yang dikembangkan berisi masalah kontekstual dengan pendekatan Realistic Mathematic Educationan (RME). Melalui matematika kontekstual, penyajian materi bahan ajar dapat diintegrasikan dengan budaya lokal di Kota Pekalongan. Oleh karena itu, penelitian ini bertujuan untuk menghasilkan bahan ajar matematika SMP dengan pendekatan Realistic Mathematic Educatioan (RME) berbasis budaya lokal untuk menanamkan nilai-nilai budaya Kota Pekalongan.

Penelitian ini menggunakan metode penelitian dan pengembangan, atau lebih dikenal dengan research and development (R\&D). Metode $R \& D$ adalah metode penelitian yang digunakan untuk menghasilkan rancangan produk baru, menguji keefektifan produk yang telah ada, serta mengembangkan dan menciptakan produk baru (Sugiyono, 2016). Tahapan yang akan dilakukan dalam mengembangkan bahan ajar ini mengadaptasi tahapan R\&D 4-D. Tahapan ini meliputi Define (Pendefinisian), Design (Perancangan), Develop (Pengembangan), dan Disseminate (Penyebaran). Artikel ini hanya membahas tentang tahap Define (Pendefinisian) dan Design (Perancangan). Adapun rincian dari setiap tahap dapat dijelaskan sebagai berikut:

\subsection{Tahap Define (Pendefinisian)}

Pada tahap ini dilakukan dengan pencarian informasi terkait masalah yang dihadapi oleh subyek penelitian yang dapat dijadikan referensi tentang bagaimana pengembangan produk yang akan dihasilkan. Kegiatan yang dilakukan berupa pencarian informasi dan data empiris melalui teori dan penelitian relevan terkait produk yang akan dikembangkan serta wawancara dengan beberapa guru matematika SMP se-Kota Pekalongan. Beberapa hal yang menjadi sorotan dalam langkah ini adalah mengenai faktor-faktor yang mungkin mempengaruhi desain produk seperti materi, budaya lokal, dan kesesuaian dari materi, pendekatan pembelajaran, serta budaya lokal Pekalongan.

\subsection{Tahap Design (Perancangan)}

Tahapan ini dilakukan perancangan produk bahan ajar berdasarkan data dan permasalahan pada tahap Define (Pendefinisian). Produk bahan ajar yang akan dikembangkan berupa buku matematika yang memuat materi satu semester, yang berisi masalah konteksual barbasis budaya di Kota Pekalongan. 
Adapun jenis dan sumber data yang diperlukan dalam penelitian ini disajikan pada tabel berikut:

Tabel 1 Data dan Sumber Data Penelitian

\begin{tabular}{l|l}
\multicolumn{1}{c|}{ Data } & \multicolumn{1}{c}{ Sumber Data } \\
\hline $\begin{array}{l}\text { Data informasi melalui teori dan penelitian } \\
\text { yang relevan }\end{array}$ & Buku, jurnal dan internet \\
\hline $\begin{array}{l}\text { Data mengenai permasalahan awal yang } \\
\text { berkaitan dengan produk }\end{array}$ & $\begin{array}{l}\text { Wawancara dengan guru SMP maupun } \\
\text { siswa SMP }\end{array}$ \\
\hline $\begin{array}{l}\text { Data mengenai kebutuhan produk yang akan } \\
\text { dikembangkan }\end{array}$ & $\begin{array}{l}\text { Angket untuk guru SMP maupun siswa } \\
\text { SMP }\end{array}$ \\
\hline $\begin{array}{l}\text { Data mengenai proses pengembangan } \\
\text { produk }\end{array}$ & Masukan dari ahli materi dan ahli media \\
\hline
\end{tabular}

\section{HASIL DAN PEMBAHASAN}

\subsection{Tahap Define (Pendefinisian)}

Sebelum dilakukan pengembangan bahan ajar, hal pertama yang perlu dilakukan adalah analisis kebutuhan. Pada tahap ini, dilakukan survey mengenai penggunaan materi budaya Pekalongan dalam pembelajaran matematika SMP. Pertanyaan penelitian yang ingin dijawab adalah :

1. Apakah pembelajaran matematika dengan menggunakan materi budaya Pekalongan dapat benar-benar membantu siswa?

2. Bagaimana model bahan ajar matematika yang mengintegrasikan budaya Pekalongan yang diinginkan oleh siswa?

Untuk itu, dikembangkan suatu bahan ajar sederhana berupa lembar kerja siswa untuk suatu materi matematika yaitu materi barisan aritmatika yang mengintegrasikan budaya Pekalongan yaitu budaya batik Jlamprang. Lembar kerja tersebut kemudian diajarkan pada salah satu SMP di Kota Pekalongan yaitu SMP Negeri 13 Pekalongan pada kelas 7A. Setelah diajar menggunakan lembar kerja tersebut, siswa kemudian diberikan soal yang memuat materi matematika yang diajarkan dan juga diberikan angket.

Soal matematika ditujukan untuk mengetahui apakah materi matematika yang diajarkan dengan menggunakan pengantar batik Jlamprang dapat dipahami oleh siswa. Sedangkan angket ditujukan untuk mengetahui apakah penggunaan batik Jlamprang dalam pembelajaran dapat membantu siswa dan alasan jawaban siswa tersebut. Setelah pembelajaran, hasil tes dan angket dianalisis.

Hasil analisis angket adalah sebagai berikut:

1. Dari 27 siswa yang mengikuti pembelajaran, semua siswa menyatakan bahwa mereka belum pernah melihat lembar kerja yang mengintegrasikan unsur budaya daerah seperti LKS yang telah dibuat,

2. Walaupun belum pernah ada yang mengalami pembelajaran dengan bahan ajar tersebut, semua siswa menyatakan bahwa LKS tersebut menarik dan mengesankan. Kalimat yang digunakan untuk menyatakan hal ini antara lain adalah "Saya dapat memahami dan saya senang karena ada mewarnainya", "bagus menarik asik dan tidak membuat bosan untuk mempelajari matematika", dan "pendapat saya mengenai LKS ini sangat menarik untuk dipahami selain itu berisikan banyak variasi". Hal ini menunjukkan bahwa 
LKS yang dibuat memberikan variasi dalam pembelajaran matematika yang mana membuat siswa tidak bosan dalam mempelajari matematika.

3. Ketika siswa diberi pertanyaan, faktor yang paling menarik dalam LKS tersebut masing-masing siswa memberikan jawaban yang berbeda. Diantaranya adalah :

a. Gambar batik yang menarik dan berwarna. Hal ini dibuktikan dengan jawaban siswa yaitu "gambar-gambar yang ada di LKS ini”, "budaya yang ada tidak hanya menghitung angka terus didampingi dengan gambar", dan "ada budaya dan tidak hanya menghitung angka dan disertai gambar"

b. Adanya kegiatan yang dapat membuat siswa belajar sambil mewarnai. Hal ini dibuktikan dengan jawaban siswa yaitu "bisa menghitung dan mewarnai".

c. Adanya kegiatan siswa yang membuat siswa tidak hanya belajar matematika tetapi juga dapat mengetahui budaya Pekalongan. Hal ini dibuktikan dengan jawaban siswa "tidak hanya menulis dan menghitung tapi kita juga bisa mengetahui budaya kota Pekalongan" dan "bisa mengenal budaya kota pekalongan".

4. Pada pertanyaan apakah motif batik jlamprang membantu dalam pemahaman materi matematika, semua siswa menjawab bahwa motif batik jlamprang dapat membantu pemahaman materi. Hal ini dibuktikan dengan jawaban siswa yaitu "ya karena lebih mudah menggunakan motif jlamprang untuk membuat barisan aritmatika", "Iya, karena memudahkan untuk menghitung cepat dalam barisan aritmatika", dan "ya karena saya suka dengan motif jlamprang".

5. Ketika siswa diminta untuk memberikan saran untuk perbaikan LKS, masingmasing siswa memiliki jawaban masing-masing. Di antaranya adalah :

a. soal diperbanyak

b. LKS dibuat untuk lebih dari satu materi

c. diperbanyak gambar

Berdasarkan uraian di atas dapat disimpulkan bahwa penggunaan budaya Kota Pekalongan dalam pembelajaran matematika dapat membantu siswa dalam memahami materi matematika. Selain itu juga dapat disimpulkan bahwa siswa menginginkan bahan ajar yang tidak hanya memuat satu materi, memiliki banyak gambar, dan memiliki jumlah soal yang banyak.

Selain dilakukan survey terhadap siswa, analisis kebutuhan awal juga dilakukan dengan mewawancarai guru. Hasil wawancara dengan ketua MGMP Matematika SMP Kota Pekalongan serta beberapa guru matematika SMP di Kota Pekalongan menyatakan bahwa selama ini memang belum pernah dibuat bahan ajar matematika SMP yang mengintegrasikan budaya-budaya Pekalongan. Mereka menyarankan bahwa pengintegrasian nilai budaya Pekalongan perlu dimasukkan ke dalam mata pelajaran matematika agar lebih menarik untuk dipelajari siswa.

Kegiatan lain yang dilakukan pada tahap ini yaitu mereview buku dan jurnal mengenai Realistic Mathematics Education (RME) untuk mengetahui karakterisrik dan prinsip dalam RME, serta manfaat penggunaan bahan ajar menggunakan RME. Terkait dengan informasi mengenai budaya Pekalongan, dilakukan kegiatan studi budaya Pekalongan, seperti kunjungan ke museum batik atau mengunjungi kegiatan-kegiatan (event) yang diselenggarakan oleh Kota Pekalongan. Dari hasil 
kunjungan ke museum batik Pekalongan, diperoleh informasi mengenai jenis dan motif batik yang bisa digunakan untuk konteks budaya dalam bahan ajar. Sedangkan hasil dari kegiatan yang diselenggarakan Kota Pekalongan diperoleh informasi mengenai tradisi Kota Pekalongan, seperti kegiatan syawalan yang di dalamnya terdapat tradisi lopis dan balon. Lopis dan balon juga digunakan untuk konteks budaya dalam pembuatan bahan ajar.

Hasil yang diperoleh pada tahap pendefinisian ini adalah :

1. Penggunaan budaya lokal Pekalongan dalam pembelajaran matematika SMP benar-benar dapat membantu siswa,

2. Bahan ajar yang dikembangkan hasuslah memuat budaya lokal Pekalongan, memuat banyak gambar ilustrasi, memiliki jumlah soal yang cukup, dan relevan dengan materi matematika SMP sesuai kurikulum yang berlaku.

\subsection{Tahap Design (Perancangan)}

Setelah ditentukan bentuk dan ketentuan bahan ajar yang dikembangkan, dimulailah tahap perancangan bahan ajar tersebut. Kegiatan yang dilakukan pada tahan perancangan (define) dimulai dengan menganalisis Kompetensi Inti (KI) dan Kompetensi Dasar (KD) mata pelajaran matematika kelas VII semester 2. Kurikulum yang digunaan yaitu kurikulum 2013. Hasil dari analisis menunjukkan bahwa materi matematika kelas VII semester 2 meliputi perbandingan, aritemetika sosial, garis dan sudut, segiempat dan segituga, serta penyajian data.

Setelah melakukan analisis Kompetensi Inti (KI) dan Kompetensi Dasar (KD), langkah selanjutnya yaitu menentukan kerangka bahan ajar. Dalam tahap ini dilakukan beberapa hal sebagai berikut:

1. Penyusunan urutan penyajian materi, yang meliputi :

a. narasi mengenai suatu budaya lokal yang mulai dikaitkan dengan materi matematika yang dapat berfungsi sebagai kegiatan awal pembelajaran seperti apersepsi atau kegiatan mengamati dalam pembelajaran dengan pendekatan saintifik,

b. materi matematika sesuai bab yang ditentukan,

c. kesimpulan,

d. latihan soal, yang meliputi pilihan ganda dan uraian, dan

e. tokoh matematika yang berkaitan dengan materi yang bersesuaian.

2. Pembuatan narasi mengenai budaya lokal Pekalongan yang telah dikaitkan dengan materi matematika.

3. Pembuatan latihan soal.

4. Tahap kompilasi dan finishing.

Adapun budaya lokal Pekalongan yang digunakan dalam bahan ajar ini adalah sebagai berikut:

Tabel 2 Budaya Pekalongan yang Digunakan

Budaya

Materi yang Dikaitkan

\begin{tabular}{l|l}
\hline Lopisan, Proses membatik & Perbandingan \\
\hline $\begin{array}{l}\text { Balon Udara Syawalan, Batik Udan } \\
\text { Liris }\end{array}$ & Garis dan Sudut \\
\hline Seketeng & Segitiga \\
\hline Fakta Batik & Statistika (Penyajian Data)
\end{tabular}


Jika diperhatikan wujud orisinalitas bahan ajar ini adalah narasi yang berusaha mengaitkan antara budaya Pekalongan dengan materi matematika. Hal ini tidak selalu mudah dilakukan. Walau demikian beberapa narasi dapat dibuat dengan menggunakan bantuan bacaan yang diperoleh di koran, buku, atau internet, sekaligus ditambah imajinasi peneliti. Berikut adalah beberapa contoh narasi yang berhasil dibuat.

1. Narasi Lopisan untuk materi perbandingan

"Lopis raksasa merupakan makanan tradisional yang terbuat dari beras ketan. Untuk tahun 2018 ini lopis raksasa dibuat dengan berat 1,4 ton dengan lingkar luar lopis $237 \mathrm{~cm}$, dan tinggi lopis mencapai $195 \mathrm{~cm}$. Sedangkan tahun lalu, tahun 2017 lopis hanya seberat 1,2 ton dan tinggi mencapai 2 meter. Pembuatan Lopis raksasa tahun 2018 membutuhkan $450 \mathrm{~kg}$ beras ketan, 250 lembar daun pisang, dan 48 batang bambu dengan lama pembuatannya selama tiga hari.

Ukuran Lopis setiap tahunnya bertambah berat. Tiga tahun yang lalu, yaitu tahun 2015, Lopis raksasa dibuat seberat $1.320 \mathrm{~kg}$ dengan tinggi lopis mencapai $203 \mathrm{~cm}$, dan lingkar luar lopis $240 \mathrm{~cm}$. Pembuatan lopis tahun 2015 menghabiskan beras ketan sebanyak yaitu 4 kuintal. Sedangkan tahun 2014, dua buah lopis raksasa yang dibuat selama lima hari memiliki berat $1.123 \mathrm{~kg}$ dan tinggi lopis mencapai 2,12 meter. Pembuatan lopis raksasa tahun 2014 membutuhkan $500 \mathrm{~kg}$ ketan, 33 batang bambu, dan 300 lembar daun pisang. Pembuatan lopis tahun 2014 melibatkan sebanyak 35 orang. Sedangkan tahun 2017, pembuatan lopis raksasa melibatkan hingga sebanyak 80 orang. Hal ini membuktikan bahwa semakin tahun warga Pekalongan semakin berantusias dalam membantu pembuatan Lopis raksasa."

Dari narasi di atas, diharapkan guru dapat memancing siswa untuk menggali informasi mengenai pembuatan lopis yang dikaitkan dengan materi perbandingan senilai dan berbalik nilai.

2. Narasi Batik Udan Liris untuk materi Garis-Garis Sejajar

"Udan liris diartikan sebagai hujan gerimis atau hujan rintik-rintik. Batik motif ini mengandung makna ketabahan dalam menjalani hidup prihatin meskipun dilanda cobaan. Di Pekalongan, batik motif udan liris merupakan salah satu motif busana daerah Wonopringgo. Batik Motif ini mengajarkan untuk tetap istiqomah dalam menjalankan ikhtiar. Oleh sebab itu, batik motif ini banyak dipakai ketika upacara pengantin sebagai doa bagi pasangan agar diberi kekuatan dan tetap istiqomah dalam menghadapi kehidupan pernikahan. Motif udan liris sendiri merupakan gabungan dari berbagai motif dalam ukuran kecil yang disusun rapat mengikuti garis-garis diagonal dengan latar belakang berwarna putih. Biasanya paling tidak terdiri dari 7 motif batik dalam ukuran kecil, diantaranya: (1) lidah api yang melambangkan ambisi, (2) setengah kawung yang melambangkan sesuatu yang berguna, (3) banji sawit yang melambangkan kebahagiaan dan kesuburan, (4) mlinjon yang melambangkan kehidupan (5) tritis yang melambangkan ketabahan hati (6) ada-ada yang melambangkan adanya keperkasaan, dan (7) watu walang yang melambangkan kesinambungan." 
Dari narasi di atas, diharapkan siswa dapat terpancing dalam mempelajari garis-garis sejajar mengingat motof batik udan liris memiliki banyak kesejajaran di dalamnya.

3. Narasi Fakta-fakta batik untuk materi penyajian data

"Kerupuk Usek adalah salah satu kuliner khas Pekalongan. Pembuatan kerupuk usek biasanya digoreng dengan pasir sehingga bebas kolesterol. Kerupuk uses biasanya dimakan bersama makanan khas Pekalongan lainnya, yaitu pindang tetel. Candra suka makan pindang tetel yang dilengkapi dengan kerupuk usek. Jika diperhatikan lebih cermat, kerupuk usek memiliki sisi yang panjangnya sama. Selain itu, kerupuk usek juga memiliki empat pojok (sudut) yang sama besar. Pada saat kerupuk usek dimasukkan ke dalam mangkok pindang tetel, Candra memotong kerupuk menjadi dua bagian dan selalu menghasilkan potongan yang sama panjang dengan potongan lainnya. Ketika kerupuk usek diputar pun selalu membentuk pola yang sama dari keadaan semula. Panjang yang dimiliki kerupuk usek $5 \mathrm{~cm}$. Pada suatu hari, Candra mendapat tugas dari $\mathrm{Bu}$ Mila untuk mencari sifat-sifat, keliling dan luas dari kerupuk usek."

Narasi di atas diharapkan dapat memancing pemikiran siswa mengenai benda-benda yang berbentuk persegi di sekitar mereka.

\section{SIMPULAN DAN SARAN}

\subsection{Simpulan}

Dari hasil tahap pendefinisian disimpulkan bahwa :

1. Penggunaan budaya lokal Pekalongan dalam pembelajaran matematika SMP benar-benar dapat membantu siswa

2. Bahan ajar yang dikembangkan hasuslah memuat budaya lokal Pekalongan, memuat banyak gambar ilustrasi, memiliki jumlah soal yang cukup, dan relevan dengan materi matematika SMP sesuai kurikulum yang berlaku.

Sedangkan tahap perancangan menunjukkan bahwa beberapa budaya Pekalongan yang dapat dibuat menjadi bahan ajar matematika antara lain adalah budaya lopisan, proses membatik, balon udara, batik udan liris, balon udara, seketeng, dan fakta-fakta mengenai batik.

\subsection{Saran}

Dengan melihat hasil penelitian di atas, saran yang dapat diberikan adalah bahwa bahan ajar yang dikembangkan perlu memasuki tahap pengembangan lebih lanjut yaitu tahap develop (pengembangan) dimana bahan ajar tersebut dapat dinilai kelayakannya melalui penilaian ahli dan penilaian user.

\section{DAFTAR PUSTAKA}

Depdiknas. (2006). Panduan Pengembangan Bahan Ajar. Jakarta : Direktorat Pendidikan Umum.

Depdiknas. (2008). Panduan Pengembangan Bahan Ajar. Jakarta: Direktorat Pembinaan Sekolah Menengah Atas Departemen Pendidikan Nasional.

Gravemeijer, K. (1994). Developing Realistic Mathematics Education. Ultrecht: Freudenthal Institute. 
Hidayanto, T., \& Irawan, E. B. (2013). Pengembangan Bahan Ajar Berbasis Realistic Mathematic Education Untuk Membangun Kemampuan Komunikasi Matematis Siswa SMP Kelas VIII Pada Materi Fungsi. Universitas Negeri Malang.

Hudojo, H. (1988). Mengajar belajar matematika. Jakarta: Depdikbud.

Koentjaraningrat. (2009). Pengantar Ilmu Antropologi. Jakarta: Rineka Cipta.

NCTM. (2000). Principles and standars for school mathematics. Reston, VA: NCTM.

Ormrod, J. E. (2003). Educational psychology (4 th ed.). New Jersey: Pearson. Education.

Samovar, L., Porter, Richard. dan McDaniel, Edwin R. (2010). Komunikasi Lintas Budaya. Jakarta: Salemba Humanika

Sugiyono. (2016). Metode Penelitian Kuantitatif, Kualitatif dan R\&D. Bandung: PT Alfabeta.

Suherman, E., dkk. (2003). Strategi pembelajaran matematika kontemporer. Bandung: UPI.

Woolfolk, A. (2009). Educational Psychology: Active Learning Edition. Yogyakarta: Pustaka Pelajar. Edisi kesepuluh. Cetakan pertama.

Zulkardi. (2001). Realistic Mathematics Education (RME): Teori, contoh pembelajaran, dan teman belajar di internet. Makalah disajikan dalam seminar sehari tentang Realistic Mathematics Education tanggal 4 April 2001. Bandung: Tidak Diterbitkan. 